\title{
Management Audit: The Personnel Recruitment Function of PT Semen Tonasa in Pangkep
}

\author{
Kordiana Sambara \\ Program Studi Manajemen, Universitas Kristen Indonesia Paulus \\ \{kordiana@ukipaulus.ac.id\}
}

\begin{abstract}
This study aims (1) to determine the procedures for job recruitment for staff functions of PT Semen Tonasa; (2) knowing the functions of personnel in meeting the objectives of PT Semen Tonasa. This research is a qualitative descriptive study. The research subject was PT Semen Tonasa. The object of research is the function of employees in the recruitment department of PT Semen Tonasa. Data collected in the form of primary and secondary data. Data collection techniques used were observing, interviews and questionnaires. This research analysis technique uses comparative descriptive. The results of this study indicate that the Human Resources recruitment function at PT Semen Tonasa has been running effectively and efficiently although there are still some weaknesses. The weaknesses that were found were, the recruitment policy making was not carried out properly, so that the results of recruitment did not match the company's needs. Some workers do not go through a proper selection process. The workforce will be unproductive because their competence is not in accordance with their needs.
\end{abstract}

Keywords: management audit; recruitment; function; personnel

\section{Introduction}

Organizations that want to succeed in achieving their goals need a guideline that needs to be given the greatest possible attention so that the continuity and survival of the organization are guaranteed. Every organization in carrying out its business activities must be able to manage its resources effectively and efficiently so that in the production process it will provide added value to the organization to be able to achieve the stated goals, namely maximum profits so that it can maintain the continuity of the organization's business in the future.

To achieve the organizational goals that have been set, it is necessary to have a concept in the form of a management audit. The concept of management audit is a tool that will increase the coefficient and effectiveness of an organization and provide an opportunity for the management (Top Management) of the organization to unify the levels of activities in the organization. Management audit techniques include a broad range of procedures, evaluation methods, policies, and approaches.

It is planned to evaluate, analyze, re-examine, and provide standards on implementation that relate to organizational activities. The objective of management audits as a whole is for the success and efficiency of the organization, so management audits are also used to evaluate 
the organization or to limit the extent of the examination of a particular part or function of the organization. The success and efficiency of an organization depend on the execution of its efforts and the attitude of its personnel. It is the responsibility of the personnel department to ensure that the organization has a positive impact on its work environment and to ensure a positive work environment is dependent on consideration of personnel in determining specific forms to carry out their duties by the management audit program.

PT Semen Tonasa, which is a state-owned company (BUMN) engaged in manufacturing, is the largest cement producer in Eastern Indonesia. The scope of the company consists of Cement production, milling machines, packaging, management services as well as research and development. Semen Tonasa, which has been officially operating since 1968, has grown and is supported by the largest distribution network and strengthened by eight cement packing units that complement the sales distribution facilities, has made PT Semen Tonasa the largest supplier in the region. The eight cement packing units are located in Bitung, Palu, Banjarmasin, Ambon, Makassar, Bali, and Samarinda, Pontianak. For that, companies need reliable personnel or employees, in principle, they will demand efficient and effective management as well. Therefore, we need a good management system in the field of personnel.

The company personnel department has determined various activities and procedures as well as references in the implementation of personnel functions, however, the current human resource function of the company can be said to have not been running optimally. Employee recruitment planning activities have not been well periodized and in its implementation, there are still obstacles. The personnel management audit at PT Semen Tonasa was carried out to find out things that needed correction and to recommend follow-up on problems related to personnel.

\section{Methodology}

The author researched PT Semen Tonasa which occupies an area of 715 hectares in Biring Ere Village, Bungoro District, Pangkep Regency, South Sulawesi, about 68 kilometers from Makassar City. The informants consist of:

a. Manager of Planning and Organizational Development

b. Planning and Organizational Development Staff

c. Personnel \& Manpower Recruitment Staff

d. Personnel Employees

The method of data collection used in this study in two ways, namely:

a. Library Research, The research was conducted by collecting data, reading books which are closely related to the discussion of this thesis, and which will be used as a theoretical basis in writing this thesis.

b. Field Research (Field Research), Information was achieved by making direct observations of the company under study. The data and information from the company were collected through visiting research objects, direct interviews with several employees and company leaders, and personnel managers. With the data needed for the problems discussed and make a questionnaire about the field of personnel.

The type of data that will be used in writing this article is quantitative data, namely data in the form of numbers obtained from company documents, reports, and other supporting data needed as well as qualitative data, namely data obtained from interviews in the form of information or explanations. from the company relevant to this research. 
The data sources used are primary data obtained from observations, interviews, submission of questionnaires to competent parties in the company, and secondary data in the form of documents and written information related to the writing of this article. The analytical method used in the writing of this article to determine whether the company's personnel function has carried out its function as it should be is a "comparative descriptive analysis method", which describes and compares the implementation of the company's personnel functions with the standards set by the company PT Semen Tonasa.

\section{Results and Discussion}

\subsection{Main Activities of PT.Semen Tonasa}

PT Semen Tonasa, which is a state-owned company (BUMN) engaged in manufacturing, is the largest cement producer in the Eastern Indonesia Region. The method used by PT Semen Tonasa to increase the company's ability to gain profits is to implement and support government policies and programs in the economic and other development fields. To achieve this goal, the company carries out activities in the following areas: Production, Providing Services, Trade, and Other businesses.

Companies can also establish or run companies and other businesses that have a relationship with the said business sector, either individually or collectively with other agencies, as long as they do not conflict with applicable laws and regulations and are in accordance with the company's articles of association. One part of the company's organizational environment is the personnel section. The main task of the personnel section is to select qualified workers through a rigorous labor recruitment process and conduct an assessment of workforce prestige. Labor recruitment is carried out by the company to fill the void in the company organization.

\subsection{Personnel Management Audit at PT Semen Tonasa in Pangkep}

The personnel function is closely related to the management of company employees. Every person who sits in the company's personnel department must perform their functions by the personnel function standards set by the company management. The function of personnel in a company plays a very important role because if the function of the workforce does not perform its function properly it will destroy the company. After all, labor is the driving force of the company's activities. The main objective of management examination of personnel functions is to determine the effectiveness of all personnel departments in handling personnel in PT Semen Tonasa. Management's examination of the personnel function is generally a very difficult task because of the extent of personnel accountability for the entire company and also the subject itself is accountability.

The personnel department at PT Semen Tonasa in Pangkep must be able to work together as a team to carry out all personnel duties which are the standards set by the company, to achieve the target of increasing the quality of resources set by the company management. The coordination that is carried out by the personnel department is by doing teamwork with all parts of the company organization.

\subsection{The Preliminary Survey}


The first stage in conducting a management audit of the workforce function is to direct a preliminary survey of the company's workforce functions. This preliminary survey was conducted so that examiners are more familiar with company policies and procedures relating to the purpose of the workforce. The introduction of policies and procedures in the personnel function will make it easier for the examiner to plan the inspection and the steps for examining the workforce function that must be carried out by the examiner at PT Semen Tonasa in Pangkep. This preliminary survey was carried out to collect background information and general information regarding the organization and personnel activities of PT Semen Tonasa in Pangkep. In this stage, the authors also try to learn and understand about the activities that exist within the company by conducting interviews, either directly or by submitting a questionnaire to management personnel related to personnel functions.

The Primary data collection in this study was carried out by distributing questionnaires to respondents, namely employees of PT Semen Tonasa in Pangkep. The criteria for respondents in this study were employees of PT Semen Tonasa in the HR department whose activities were related to the recruitment process, and respondents who returned the questionnaire. The number of questionnaires returned $100 \%$ of the number of questionnaires distributed was 30 questionnaires. The distribution process to data collection was carried out from 18 January to 23 January 2018. The returned questionnaires can be further processed to be used as research data. Complete data can be seen in Table 5.1 below.

Table 1. Questionnaire Return Rate

\begin{tabular}{cc} 
Table 1. Questionnaire Return Rate & \\
\hline Information & Amount of Data \\
\hline Number of questionnaires sent & 30 \\
Number of non-returned questionnaires Number of & 0 \\
questionnaires returned & 30 \\
Number of questionnaires that can be used & 30 \\
\hline Sampel & 30 \\
Responden rate & $(30 / 30) \times 100 \%=100 \%$ \\
\hline Source: Primary Data Processed (2018)
\end{tabular}

In the preliminary survey, the authors interviewed the Planning and Organizational Development Staff Manager directly, Did all employees experience the same process during the recruitment process? "In the recruitment process at PT Semen Tonasa, there are 3 different stages of the recruitment process, namely: Based on the level of education (S1 / D3). There is a third party, where the third party is an external party who works with PT Semen Tonasa and Semen Indonesia. There is a scholarship given from PT Semen Tonasa in collaboration with the campus which selects outstanding students and will later be selected again to become employees at PT Semen Tonasa. Based on the recruiting environment around the company."

Do all employees experience the same process during the recruitment process? "Yes, the recruitment program is in accordance with the strategy to achieve company goals because the company conducts training before becoming organic employees."

Interviewing Planning and Organizational Development Staff, When did the company do the recruitment? "The company PT Semen Tonasa performs recruitment when there is a shortage of employees, but in the recruitment process a period of 2 years or once a year to save budget costs for new employee recruitment."

Interviewing Human Resources \& Manpower Recruitment Staff, Has the recruitment process been running economically, efficiently, and effectively to obtain human resources that match the qualifications needed by the company? "Yes, the recruitment process has been 
running economically, efficiently, and effectively to obtain Human Resources according to the qualifications needed by the company."

In this preliminary survey, the authors conducted interviews with personnel-related to human resource functions and other functions. These interviews were conducted either directly or by submitting a questionnaire to management personnel related to personnel functions. The results of interviews in the stage of preliminary survey conducted on company personnel can be seen from the following table:

Table 2. The results of interviews in the stage of preliminary survey conducted on company personnel Personnel Function Questionnaire

\begin{tabular}{lll}
\multicolumn{2}{c}{$\begin{array}{c}\text { Personnel Function Questionnaire } \\
\text { Company Name: PT Semen Tonasa } \\
\text { Name and title of the interviewee }\end{array}$} \\
\hline \multicolumn{2}{c}{ Employee Name } & \multicolumn{1}{c}{ Position } \\
\hline 1. & Rifki Satria Pradita & Manager of Planning and Organizational Development \\
2. Muh.Ilyas S & Staff of Planning and Organizational Development \\
3. & Faisal Tanjung & Staff of Recruitment Human Resources and Labor \\
\hline
\end{tabular}

\subsection{Management Inspection Questionnaire on Personnel Functions of PT Semen Tonasa}

A questionnaire consisting of 5 questions has been used by several previous studies. This questionnaire has been distributed directly to 30 respondents, namely managers, HR recruitment staff, and HR employees.

Table 3. A questionnaire consisting

\begin{tabular}{|c|c|c|c|c|}
\hline \multirow{2}{*}{ No. } & \multirow{2}{*}{ Questions } & \multicolumn{2}{|c|}{ Answer } & \multirow{2}{*}{ Comment } \\
\hline & & Yes & No & \\
\hline & Purpose of Review and Testing & & & \\
\hline & Control: & & & \\
\hline & $\begin{array}{l}\text { Assess, test the effectiveness of recruitment and identify } \\
\text { weaknesses in HR recruitment }\end{array}$ & & & \\
\hline 1. & Is the recruitment policy well recorded? & 28 & 2 & \\
\hline 2. & $\begin{array}{l}\text { Has the recruitment explicitly informed the requirements that } \\
\text { must be met by prospective workers by the needs of the } \\
\text { company PT Semen Tonasa? }\end{array}$ & 30 & 0 & \\
\hline 3. & $\begin{array}{l}\text { Has the recruitment utilized the most appropriate source of } \\
\text { labor? }\end{array}$ & 30 & 0 & \\
\hline 4. & Does the recruitment process use the right method? & 30 & 0 & \\
\hline 5. & $\begin{array}{l}\text { Has the recruitment process been running economically, } \\
\text { efficiently and effectively to obtain human resources that } \\
\text { match the qualifications required by the company PT Semen } \\
\text { Tonasa? }\end{array}$ & 30 & 0 & \\
\hline
\end{tabular}

So, the number of "yes" answers from 30 respondents was 148 in all of the five questions, and there were 2 respondents' answers who answered "no" to question number 1 because when reading the question, the respondent did not focus on answering the questionnaire questions. But from the overall answer, the respondent is an illustration that the company is running effectively and efficiently. After conducting a preliminary survey at PT Semen Tonasa in Pangkep, it was found that the company's recruitment policy was not well documented.

\subsection{The Review and Testing of Management Control}


The organizational structure in the company is the overall management control system. The next stage in the implementation of management inspection is to review and test the management control system based on the data and findings obtained in the preliminary survey.

In the audit report, the recommendations for improving the management control system for personnel functions must be explained. Recommendations and suggestions for improvements are suggestions, and implementation of these recommendations or suggestions is the policy of the company leadership. With the results of the review and testing of the management control of the personnel function, the examination should focus on the elements deemed potential for irregularities. The results of the review and testing of the Management control system on the performance of the personnel function can be seen in the following table:

Table 4. Strengths of Management Control Systems

\begin{tabular}{c}
\hline STRENGTHS OF MANAGEMENT CONTROL SYSTEMS \\
\hline There is an organizational structure and job description that regulates the \\
authorities, duties and responsibilities of each division. \\
No concurrent duties are carried out in personnel functions.
\end{tabular}

Table 5. The Weakness of the Control System

\begin{tabular}{lll}
\hline Control System Weaknesses & Mistakes That May Happen & Foundable Testing \\
\hline & $\begin{array}{l}\text { Each recruitment policy can be } \\
\text { different because there is no } \\
\text { previous recruitment }\end{array}$ & $\begin{array}{l}\text { Each recruitment process } \\
\text { must have a well- } \\
\text { structured report, so that } \\
\text { The company's recruitment } \\
\text { policies are not well recorded. } \\
\text { policies are not well } \\
\text { documented. }\end{array}$ \\
\hline
\end{tabular}

Source: PT Semen Tonasa in Pangkep

\subsection{The Detailed Examination}

In this stage, the authors gather evidence to support the findings obtained in the previous phase. So that writing can determine what things/actions are performed by management and employees of the personnel function which is irregularities.

The detailed examination summary can be seen in the table below

Table 6. Summary of Detailed Inspections on Personnel Functions of PT Semen Tonasa

\begin{tabular}{|c|c|c|}
\hline Condition & Criteria & Recomendation \\
\hline $\begin{array}{l}\text { The company's } \\
\text { recruitment policies } \\
\text { are not well } \\
\text { recorded. }\end{array}$ & $\begin{array}{l}\text { the company's recruitment policy } \\
\text { must be well documented so that } \\
\text { it meets the competencies } \\
\text { required by the company. }\end{array}$ & $\begin{array}{l}\text { The recruitment policy must be } \\
\text { well documented so that the } \\
\text { workforce needs can be } \\
\text { measured and fulfilled } \\
\text { according to the required } \\
\text { capacities and competencies. }\end{array}$ \\
\hline
\end{tabular}

After conducting a detailed examination of the personnel function at PT Semen Tonasa, the findings obtained from the detailed examination were that the company's recruitment policy was not well documented.

\section{Conclusion}


Based on the description in the previous chapter, it can be concluded that the personnel function of the human resource recruitment department at PT Semen Tonasa has been running effectively and efficiently but there are still some weaknesses such as the recruitment policy at PT Semen Tonasa company which is not well documented, as a result, the results of recruitment can because excess labor and are not following their competence so that the workforce in the company is not productive. Based on the results of the study, the researchers provided useful suggestions for the management and implementation of human resource programs at PT Semen Tonasa. The suggestions given were that PT Semen Tonasa should have a well-documented recruitment policy so that the need for labor can be more measured and can be fulfilled by the required capacities and competencies.

\section{References}

[1] Abdul Halim, 2001. Auditing I, Edisikedua. Unitpenerbit dan percetakan (UPP) APM YPKN. Yogyakarta.

[2] Adni, A. B., Susilo, H., \&Prasetya, A. (2014). AUDIT MANAJEMENPADA FUNGSISUMBER DAYAMANUSIA (Studipada Fungsi Pengembangan Organisasi , Rekrutmen-Seleksi-Orientasi , Pelatihan\&Pengembangan SumberDayaManusia, dan Penilaian KinerjaDepartemen Pengembangan SumberDayaManusia,13(1), 1-10. https://doi.org/10.1051/shsconf/201417

[3] Bayangkara,IBK. 2008.Audit Manajemen Prosedir danImplementasi.SalembaEmpat, Jakarta.

[4] Maharani,L.G. D. P., \& Sari, M. M. R. (2014). Persepsikaryawan Atas Audit Manajemensumber Daya Manusia Pada Kinerja Karyawan,3, 538553.https://doi.org/10.1017/CBO9781107415324.004

[5] Mathis.L.Robert dan Jackson.H.John. 2001, Manajemen SumberDayaManusia.Jakarta:Buku Kedua.

[6] Nawawi, Hadiri, H., 2001. Manajemen SumberDayaManusia UntukBisnis YangKompetitif, Cetakan Kedua, Gadjah MadaUniversityPress, Yogyakarta.

[7] Ranupandojo Heidjarahman, dan Suad Husnan, 2001. Manajemen Personalia, Edisi Keempat, BPFE,Yogyakarta.

[8] SimamoraHendry, 2002.Auditing, JilidSatuCetakan Pertam, Unit Penerbit danPercetakan APM YPKN,Yogyakarta.

[9] TunggalAmin Wijaya, 2002. Manajemen Audit,Kotemporer, EdisiRevisi, Penerbit RinekaCipta, Jakarta.

[10] Tunggal, Widjaja, Amin,2001. Audit Operasional(Suatu Pengantar).Harvanindo, Jakarta.

[11] Widjayanto, Nugroho,2002. Audit Operasional Organisasi,LembagaPenerbitFakultas EkonomiUniversitasIndonesia, Jakarta. 